\title{
LATIN TERMINOLOGY IN THE PROFESSIONAL SPEECH OF FUTURE VETERINARIANS
}

\section{ЛАТИНСЬКА ТЕРМІНОЛОГІЯ У ПРОФЕСІЙНОМУ МОВЛЕННІ МАЙБУТНІХ ВЕТЕРИНАРІВ}

The article deals with the influence of Latin terminology on the professional language of future veterinarians. It is known that knowledge of Latin is needed today by specialists in various fields of science, since social and political, biological, technical, medical, legal, philological and other scientific terms originate mainly from Latin. First of all, Latin is related to anatomical, medical and pharmacological nomenclature. At the same time, Latin and Latinized Greek vocabulary is the main source of complement to the ever-growing terminology in all fields of science. Latin is a kind of building material from which new terms are formed. It has been found out that Latin is the basis of terminology and no science can do without knowing these basics. Latin is multifaceted. As a result of the study, it has been found that over the past decade, high school teachers have been concerned about the growing number of grammatical errors that characterize students' written work. Many years of practice indicate that even when acquiring prescription skills, students have many questions and complications that require some effort on the part of the teacher to eliminate them. These questions are related to the names of the dosage forms, preparations, plants and clear structure of the recipe.

During the study it was noted that the productivity of mastering the terms and their active use in oral and written Latin proficiency largely depends on a system of preparatory exercises, sequentially aimed at both translation and thoughtful mastery of terminology, and the activation of speaking and listening skills, need to apply this terminology to specific work situations. Exercises related to mastering the scientific terminology of students are provided. Equally effective are exercises of a reproductive nature that perform a familiarizing function. The study found that terminological vocabulary is of great importance for scientific and professional communication, facilitating its intellectualization, the process of knowledge acquisition and implementation in further professional activity. Terminology is a means of expanding an active professionally determined vocabulary.

Key words: scientific terminology, Latin, professional language, term, teaching methods.

y статmі розглядається вплив латинської термінології на професійне мовлення майбутніх ветеринарів. Відомо, що знання латинської мови в наш час потрібне спеціалістам різних галузей науки, оскільки соціально-політичні, біологічні, технічні, медичні, юридичні, фрілологічні та інші наукові терміни походять переважно з латинської мови. Перш за все латинська мова пов'язана з анатомічною, медичною та фрармакологічною номенклатурою. Разом з тим латинська $і$ латинізована грецька лексика $є$ основним джерелом поповнення безперервно зростаючої термінології в усіх галузях науки. Латинська мова - це своєрідний будівельний матеріал, з якого утворюються нові терміни. З'ясовано, що на базі латинської мови формується основа термінології, жодна наука не може обійтися без знання цих основ. Значення латинської мови багатогранне. В результаті дослідження було виявлено, що протягом останнього десятиріччя викладачі вищої школи із занепокоєнням констатують зростання кількості грубих граматичних помилок, що характеризують письмові роботи студентів. Багаторічна практика свідчить, що і під час набуття навичок виписування рецептів у студентів виникає багато питань $і$ ускладнень, які потребують певних зусиль з боку викладача для їх усунення. Ці питання пов'язані з назвами лікарських срорм, препаратів, рослин та чіткою структурою рецепта. Під час дослідження було відзначено, що продуктивність засвоєння термінів та їх активне використання в усному та писемному латинському фраховому мовленні багато в чому залежить від системи підготовчих вправ, послідовно спрямованих як на переклад та засвоєння термінології, так і на активізацію вмінь говоріння та слухання, необхідних для застосування цієї термінології в конкретних робочих ситуаціях. Надаються вправи, пов'язані із засвоєнням наукової термінології студентами. Не менш есективним $\epsilon$ і вправи репродуктивного характеру, що виконують ознайомлювальну фуннкію. Дослідженням встановлено, що термінологічна лексика має велике значення для науково-виробничої комунікації, сприяючи ї інтелектуалізації, полегшує процес засвоєння знань та реалізації їх у подальшій фраховій діяльності.

Ключові слова: наукова термінологія, латинська мова, професійне мовлення, термін, методики навчання.
The problem statement in general. Entry of Ukraine into the European and world social and cultural space requires changes in the training of specialists. The modern period of our state development opens up great opportunities for updating the content of education, and therefore the education of the spiritually rich and professionally trained generation. Higher education reform, in particular its commitment to humanization and education humanization, makes it possible to fulfill the social order of society for the formation of future professionals in various fields of professional communication. According to L. Matsko, "the level of proficiency in the professional metalanguage (term systems, phraseology, composition and genre forms of text-forming) and the level of linguistic image of social roles (politician, statesman, leader, scientist, etc.)" are the expression of linguistic culture and constitute the highest level formation of linguistic personality [4, p. 2].

Mastering the basics of any profession begins with a system of general and professional knowledge, assimilation of phraseology and terminology of this 
area, which will facilitate both successful studies at the university, and in further professional activity. "For free fluency in oral and written forms of professional communication, students of non-philological universities must have a considerable active vocabulary of professional terminology" [6, p. 62], because the specificity of this style of communication is determined first of all by a large number of terms that are widely used in professional activity. Thus, the basis of the professional vocabulary of the specialist is composed of special terms (approximately 60\%), the rest are general scientific terminology and common lexemes.

Analysis of recent investigations and scientific publications. In the modern domestic linguistic and methodical literature there is a considerable amount of scientific researches devoted to the problem of formation and improvement of speech competence of young people, in particular, the development of general methods of students' linguistic competence formation (L. Baranovskaya, L. Golovata, L. Luchkina and others).

There are also studies in which certain types of work with professional terminology are presented (N. Kostrytsia, Y. Janusz, T. Rukas, N. Totskaya and others). However, a common system of working with scientific terminology that could be used in the teaching students of Latin terminology has not been developed yet.

The purpose of the article is to analyze the influence of Latin scientific terminology on the professional language of future veterinarians.

Presentation of the main research material. Teaching the Latin language at an agrarian university involves the study of vocabulary, grammar, and terminology. One of the urgent tasks of the development of linguistic abilities of students is the development of intensive forms of learning. The main point of theoretical and practical studies of the intensification of teaching foreign languages in general, and the Latin language in particular, is the so-called comparative method (consciously-comparative method), which has become widespread. The essence of this method is that comparing the mother tongue and a foreign language in the methodological and linguistic terms at certain stages in the development of methodological and linguistic thought of students not only effectively correlate, but stimulate each other. At the same time, it is necessary to emphasize the fact that the mother tongue is the basis of a consciously comparative teaching method. The choice of the native language as the base language in binary comparison for educational purposes is due to the high degree of proficiency in it.

When studying vocabulary in anatomical terminology, students see how much Latin has firmly entered the English language. So already at the first obligatory lexical minimum, students do not experience difficulties. However, recognition of common root words during listening is not as simple as when reading due to differences in pronunciation in English and Latin. Therefore, in the formation of a mechanism for recognizing common root words in speech, special exercises are necessary, first with visual support, then without it.

The names of adjectives in languages also appeared as a result of the subjective perception of the world by native speakers. This is especially true for adjectives. And there are adjectives, the meaning of which is clear to students who know English. From all of the above it follows that in terms of perception and understanding of the lexical material of the Latin language, students who know English have practically no problems.

Teaching any language today is complicated by the overall low level of education and literacy of the population, which is getting worse. This is mostly true of the younger generation and is observed primarily in the native language (both Russian and Ukrainian). Over the last decade, high school teachers have been concerned about the growing number of grammatical errors that characterize our students' writing, their ignorance of cases questions, their inability to distinguish adjectives from participle, the lack of understanding of the principles of nouns and adjectives sequence.

There are many factors that cause this situation. These include the gradual transition of educational institutions to Ukrainian language of teaching, which causes some difficulties, given, for the most part, the Russian-language orientation of the population of Eastern Ukraine and poor language teaching in secondary schools, the quality of modern school textbooks, which is a separate problem. The situation is aggravated by the fact that modern young people hardly read, preferring to a computer, television and tape recorder. But if they read, the situation would be almost worse because of the fact that bookshops and newsstands offer today concerning the content and literacy of the texts.

At foreign language departments of higher agrarian educational institutions, the situation is complicated by new requirements for educational programs and the allocation of academic hours. Thus, 72 hours are envisaged for studying the Latin language course, only 32 of which are for audience work and 40 hours for students' independent work. Such timing cannot be considered appropriate, since the course is not a history course or any other social discipline that a student can learn on his own by reading the textbook and answering control questions.

Therefore, there is no lecture course in Latin, which, like any other language, can be mastered only during practical classes. The Latin course is not just about mastering certain Latin information, it is a student's intensive work under the guidance of a teacher to acquire skills in the use of special terminology, skills in recognizing term elements in a variety of sim- 
ple and complex terms, understanding these terms and derivatives. It is only possible to acquire these skills in an audience where the student pronounce a particular morpheme many times, writes it on a blackboard, hears it spoken or written by others, and thus leaves it in his long-term memory. We do not think that he should be able to do all this work on his own without the guidance and correction of the teacher.

Many years of practice indicate that even when acquiring skills in prescription writing, students have many questions and complications that require some effort on the part of the teacher to eliminate them. These questions are related to the names of the dosage forms, preparations, plants and clear structure of the recipe. Consideration should also be given to the fact that first-year students begin learning Latin from scratch. Only part of them (students from lyceums, grammar schools, and colleges) has some information about Latin. For most of the students this discipline is terra incognita.

The situation is aggravated by the fact that some veterinarians have recently been told that Latin is an outdated discipline and that studying it in agrarian universities is more a tribute to tradition than an urgent necessity. Latin terms that illustrate a specific term in the native language are excluded. Young teachers of specific disciplines do not use Latin terms in parallel with Ukrainian or Russian, and do not require students to have a compulsory knowledge of them, as it was ten to fifteen years ago. This position, although natural, in view of the above-mentioned process of a general decline in the level of a society's culture. But who, if not doctors, should know that any national medical speech is abandoned with Latin and Greek terms, and it is very difficult for a student to perceive special disciplines in his native language without knowledge of the basics of Latin.

Let us turn to some examples. At first glance, there is no need to learn Latin term "nucleus", because it is not used in Ukrainian in this form, but in the first course at lectures on histology, students encounter the term "perinuclear", which they cannot understand without knowledge of the corresponding Latin morpheme. The term "endothelium" also means to understand the Latin root (from the tela - tissue) and the Greek prefix (endo - inside). The teacher will surely give an explanation of the meaning of many terms and the student will understand what it is about, but when there are a lot of such terms, there can be no question of the students' qualitative perception of the topic of the lesson, textbook, reference book or article. Not to mention the language of clinical disciplines, where at every step we meet: penetrating, perforative, ulcerogenic, ventricular, somatic, ischemic, posthemorrhagic, epigastric and so on.

The teachers of clinical disciplines are simply unable to explain every word they use when teaching material. Students need to learn the meanings of all these and many other terms in their first year of learning Latin. Teachers in practical classes should bring to the automaticity students understanding of Latin and Greek meaningful morphemes, which is impossible to do in modern conditions.

Memorization of words is an integral part of classes in the Latin language. Students have special notebooks for writing down new words. Words are memorized in vocabulary form, which helps with grammar exercises. After conducting a survey among students about the difficulties of learning the Latin language, it was revealed that for many of them the main problems are: a large amount of time spent on cramming, and a language barrier due to poor knowledge.

The productivity of mastering the terms and their active use in oral and written Latin vocabulary depends largely on a system of preparatory exercises, sequentially aimed at both the translation and thoughtful mastery of terminology, and the activation of the speaking and listening skills required for the specific use of this term situations.

It should be noted that the teacher cannot be limited to creative tasks that promote the active independent use of terminological vocabulary in accordance with the situation. The exercises of a reproductive nature that perform a familiarizing function are equally effective:

- to give oral interpretation to professional terms in their native language;

- to sort out the terms to the proposed definitions;

- to conclude a terminological vocabulary concerning a particular disease;

- to give an explanation of certain terms;

- to create as many terms as possible, using the most common term elements;

- to retell the material of the previous lecture, paying attention to the pronunciation and use of professional terminology.

Students are helped to feel the specifics of the concepts being studied, illustrate the features of normative professional broadcasting in comparison with everyday conversational exercises of a comparative type, translation exercises that identify "along with the common features that are characteristic of closely related languages, also peculiar features that are nationally specific" [5, p. 26]. Exercises of these types make it possible to analyze the peculiarities of the concepts being learned at different linguistic levels - phonetic, lexical, grammatical and stylistic. The most appropriate for the formation of vocational competence on the basis of scientific and professional terminology is the use of texts in the specialty - small in volume, accessible in content, rich in words, stable phrases and grammatical constructions characteristic of the language of the specialty. Only at the text level do the professional terms learned stand as a coherent communication system, suitable for use in certain work situations. 
The study of clinical terminology, which is part of the course, does not require active use of grammatical material. The student needs to memorize the terminological elements of Greek and Latin origin that underlie the derivation of medical terms. Clinical terminology refers to a variety of objects, processes, phenomena related to the prevention, diagnosis of diseases, their differentiation and methods of examination and treatment of sick animals. Student should know and understand that the possession of medical terminology and the ability to use it is an integral part of the professional competence of the future veterinarian.

Thus, terminological vocabulary is of great importance for scientific and professional communication, facilitating its intellectualization, the process of mastering knowledge and its implementation in further professional activity, deepens students' knowledge about the signs of the concepts being studied. Terminology is a means of expanding an active professionally determined vocabulary, and increases the level of representatives of the future Ukrainian intellectuals.

Conclusions and prospects for further research. Not very favorable conditions for teaching the Latin language negatively affect the quality of student knowledge, which lose its fundamental nature, gradually leading to the decline of the best national traditions in the field of education. Therefore, it is considered advisable to combine the efforts of teachers of the Latin language, medical and pharmaceutical higher schools to attract the attention of the pedagog- ical community and the ministry to these problems in order to solve them. Learning the Latin language is an integral part of preparing future doctors. The purpose of studying the terms remains one - to create the basis of the terminological system of a professional language. Of course, the conceptual content of the terms may be complete and strictly disclosed only in the study of special disciplines in the respective departments. Successful learning the Latin language will only contribute to their easier learning and use.

\section{REFERENCES:}

1. Барановська Л.В. Навчання студентів професійного спілкування : монографрія. Біла Церква, 2002. 256 c.

2. Барановська Л.В. Теоретико-методичі основи навчання просресійного спілкування студентів вищого аграрного навчального закладу : автореф. дис. ... д-ра пед. наук: спец.13.00.04 «Теорія і методика професійної освіти». Київ, 2005. 43с.

3. Кацман Н.Л. Методика преподавания латинского языка. Москва : Гуманит. изд. центр ВЛАДОС, 2003. 256 c.

4. Мацько Л.І. Матимемо те, що зробимо. Дивослово. 2001. № 9. С. 2-3.

5. Михайлюк В.О. Переклад у фрормуванні культури ділового мовлення. Дивослово. 1999. № 7. C. 26-29.

6. Тоцька Н.І. Методика роботи викладачів вищого технічного навчального закладу над українським профресійним мовленням студентів. Дивослово. 2003. № 1. С. 62-65. 